\title{
EFEKTIVITAS PEMBERIAN LAYANAN INTERVENSI MUSIC THERAPY UNTUK MEREDUKSI ACADEMIC ANXIETY MAHASISWA TERHADAP SKRIPSI
}

\author{
Dominikus David Biondi Situmorang ${ }^{1)}$ \\ ${ }^{1)}$ Universitas Katolik Indonesia Atma Jaya, Jakarta, Indonesia \\ E-mail: david.biondi@atmajaya.ac.id
}

\begin{abstract}
Abstrak. Di Indonesia, skripsi masih menjadi tugas akhir yang cukup menakutkan bagi sebagian besar mahasiswa. Banyak di antaranya melakukan perilaku bunuh diri sebagai dampak dari academic anxiety yang berlebihan terhadap skripsi ini. Konselor pendidikan sebagai salah satu agen peubah internal perguruan tinggi diharapkan mampu mengatasi permasalahan yang acapkali terjadi setiap tahunnya. Namun, strategi intervensi konseling konvensional yang selama ini diberikan menunjukkan hasil yang kurang efektif, sehingga dirasa perlu untuk beralih ke sebuah pendekatan modern yang lebih efektif dalam mereduksi academic anxiety mahasiswa, yaitu integrative approach melalui intervensi music therapy.
\end{abstract}

Kata Kunci: Music Therapy; Academic Anxiety; Skripsi; Mahasiswa; Konselor Pendidikan

\section{Pendahuluan}

Dewasa ini, skripsi merupakan tugas akhir yang mengakibatkan kecemasan yang tinggi bagi sebagian besar mahasiswa di Indonesia [1]. Rasa cemas terhadap skripsi seperti ini merupakan bentuk academic anxiety di tingkat perguruan tinggi [2]. Jika hal ini terus dibiarkan, maka akan mengakibatkan gejala-gejala negatif dalam aspek fisik maupun psikis yang dapat menghambat mahasiswa dalam proses studi mereka. Sebagian besar mahasiswa yang mengalami academic anxiety terhadap skripsi ini akan cenderung melakukan hal-hal negatif yang dapat merugikan dirinya sendiri, salah satu perilaku yang paling ekstrim yang kerapkali terjadi ialah perilaku bunuh diri [1]. Mengenai hal tersebut, dirasa cukup penting untuk melakukan sebuah layanan intervensi yang bersifat preventive untuk mencegah fenomena ini di bagian hulu, dan melakukan layanan intervensi yang bersifat curative untuk mengobati mereka yang telah mengalami academic anxiety ini di bagian hilir. Para konselor pendidikan di perguruan tinggi diharapkan untuk selalu bersikap pro-aktif dalam mencegah maupun mengobati para mahasiswa yang mengalami academic anxiety terhadap skripsi ini. Selain itu juga, para konselor pendidikan diharapkan dapat melakukan sebuah layanan intervensi konseling yang lebih efektif dan optimal dalam menanggulangi permasalahan ini. Salah satu layanan intervensi konseling modern yang ditawarkan oleh integrative approach adalah melalui music therapy ([3], [4]).
Music therapy dalam penerapannya dapat meningkatkan produksi keempat hormon positif yang ada di dalam tubuh manusia, yaitu endorphin, dopamin, serotonin, dan oksitosin. Fungsi dari keempat hormon positif tersebut dapat membuat tubuh menjadi lebih rileks, mereduksi kecemasan atau stres, meningkatkan kebahagiaan, meningkatkan kecerdasan, dan meningkatkan rasa percaya diri ([5], [6]). Pemberian music therapy sebagai layanan intervensi untuk membantu mahasiswa dalam mereduksi academic anxiety akan jauh lebih efektif dibandingkan dengan layanan intervensi konseling konvensional yang selama ini dilakukan oleh konselor pendidikan, karena dengan music therapy mahasiswa dapat mereduksi kecemasannya terhadap skripsi dan meningkatkan rasa percaya dirinya dalam menyelesaikan skripsi.

\section{PEMBAHASAN}

\section{DEFINISI MUSIC THERAPY}

Secara etimologis, music therapy (terapi musik) terdiri dari dua kata, yaitu "music" dan "therapy". "Music" digunakan untuk menjelaskan media yang digunakan secara khusus dalam rangkaian terapi, sedangkan kata "therapy" berkaitan dengan serangkaian upaya yang dirancang untuk membantu seorang individu dalam mengentaskan permasalahannya [7]. Biasanya, kata "therapy" digunakan dalam konteks permasalahan individu yang meliputi aspek fisik maupun mental [8]. Dalam kehidupan sehari-hari, terapi terjadi dalam berbagai bentuk, misalnya, para psikolog akan mendengar dan berbicara dengan klien melalui tahapan 
konseling yang terkadang perlu disertai dengan bantuan terapi ([9], [10], [11]), dan ahli fisioterapi akan memberikan berbagai latihan fisik untuk mengembalikan fungsi otot tertentu yang dimiliki oleh seorang individu ([12], [13], [14], [15]). Maka, seorang terapis musik akan menggunakan musik dan aktivitas musik untuk memfasilitasi proses terapi dalam membantu mengentaskan permasalahan yang dialami oleh kliennya ([6], [7], [16], [17]).

Terapi musik adalah profesi yang telah muncul selama lima puluh tahun terakhir dari berbagai disiplin profesional di berbagai negara [6]. Oleh karena itu, proses mendefinisikan terapi musik baik sebagai profesi dan sebagai disiplin ilmu dapat bervariasi, tergantung pada orientasi dan perspektif kelompok tertentu berdasarkan praktisi yang bekerja sebagai terapis, klien yang diberi perlakuan, dan kekhasan budaya yang dianut [16]. Definisi umum mengenai terapi musik itu bersifat inklusif, dan berfokus pada fungsi musik sebagai media terapi, serta mendefinisikan untuk siapa terapi dimaksudkan [17]. Namun, proses mendefinisikan terapi musik tercermin dalam cara profesi ini diimplementasikan ke dalam setiap budaya yang ada di negara masing-masing. Dari cara tersebut, hal yang harus dipertimbangkan ialah mengenai tiga faktor utama, yaitu latar belakang profesional praktisi, kebutuhan klien, dan pendekatan yang digunakan dalam pengobatan [7].

Dalam rumusan The American Music Therapy Association (dalam [6]), dikatakan bahwa "terapi musik adalah suatu profesi yang menggunakan musik dan aktivitas musik untuk mengatasi berbagai masalah dalam aspek fisik, psikologis, kognitif, dan kebutuhan sosial individu" (p. 27). Dari aspek fisik, terapi musik sebagai sebuah teknik yang digunakan untuk penyembuhan suatu penyakit dengan menggunakan bunyi atau irama tertentu yang diberikan oleh seseorang yang berprofesi sebagai seorang dokter dengan spesialisasi psikiatri ([12], [13], [14], [15]). Dari aspek psikologis dan kognitif, terapi musik diberikan oleh seseorang yang berprofesi sebagai psikolog atau psikoterapis ([9], [10], [11]). Sedangkan dari aspek kebutuhan sosial individu, terapi musik dapat diberikan oleh seseorang yang berprofesi sebagai seorang konselor ([18], [19], [20]). Dalam setiap praktik profesionalnya, seorang terapis musik dapat menggunakan beberapa jenis musik tertentu untuk membantu para klien dalam mengentaskan permasalahannya, yaitu dengan menggunakan musik klasik, instrumentalis, maupun slow music (Potter \& Perry, 2005 dalam [16]). Terapi musik adalah proses yang menggabungkan antara aspek penyembuhan musik itu sendiri dengan proses konseling untuk membantu konseli dalam mengentaskan permasalahan yang melingkupi hal fisik atau tubuh, emosi, mental, spiritual, kognitif, dan kebutuhan sosial seseorang [6].

\section{KONSEP MUSIC THERAPY DALAM KEILMUAN BIMBINGAN \& KONSELING}

Dalam keilmuan Bimbingan \& Konseling (Psikologi Pendidikan), terapi musik dapat dijadikan sebagai salah satu bentuk intervensi yang dapat digunakan oleh para konselor dalam praktik konselingnya ([3], [4]). Melalui musik, proses rapport antara konselor dan konseli dapat berlangsung dengan baik, karena musik merupakan bahasa yang universal dan dapat menembus batas-batas multikultural [17]. Dalam sejarahnya, sejak peradaban yang lalu musik dipergunakan oleh manusia dalam proses penyembuhan di berbagai kebudayaan di dunia, sehingga saat ini musik dapat digunakan dalam proses konseling modern [21]. Proses konseling modern saat ini memang harus menarik dan menyenangkan, karena dapat membuat konseli bersikap lebih terbuka dan termotivasi untuk berubah ke arah yang lebih baik, sehingga proses konseling menjadi lebih efektif [18].

Efektivitas proses konseling dengan menggunakan terapi musik sangat terapeutik, karena melalui terapi musik dapat membantu konselor dan konseli melakukan reframing ide, memfokuskan perspektif, eksternalisasi emosi, dan memperdalam pemahaman dari sebuah pengalaman atau masalah [19]. Dengan demikian, ada sebuah proses katarsis yang terjadi dalam proses konseling melalui terapi musik ini. Konseli dapat menemukan beberapa penghiburan dan bahkan beberapa resolusi penuh makna, terutama jika mereka berbagi kata-kata dari sebuah lagu dengan konselor. Dalam proses konseling, musik dapat membantu konseli dan konselor menemukan tujuan yang hendak dicapai, sehingga membantu konseli melihat berbagai kemungkinan dan membantu mereka untuk menyadari hal-hal positif yang dapat dilakukan untuk membantu mereka menyelesaikan masalah [20].

Seorang konselor di dalam setiap praktiknya dituntut untuk memiliki rasa empati, kesabaran, ketulusan untuk membantu orang lain, bijaksana, penuh pengertian, namun juga fleksibel dan memiliki rasa humor ([17], [18], [19], [20], [21]). Semua persyaratan di atas penting karena dalam praktiknya, konselor bekerja dengan individu yang sedang menghadapi masalah, menderita sakit, mengalami stres berat, membutuhkan perhatian lebih karena keterbatasanketerbatasannya, atau tersingkir dari relasi sosial yang wajar karena berbagai sebab baik secara internal maupun eksternal ([8], [22]).

Seorang konselor juga harus menjunjung tinggi etika profesi, yaitu dengan menjaga kerahasiaan data konseli, menghormati hak-hak konseli, melakukan prosedur konseling dengan benar, dan menjaga etika kerja profesional baik dengan sesama konselor maupun dengan profesi terkait lainnya ([17], [18], [19], [20], [21]). Oleh karena itu, pendidikan dan pelatihan untuk menjadi seorang konselor yang dapat memberikan terapi musik itu bersifat lintas bidang, karena terapi musik adalah bidang multidisiplin yang terkait erat dengan bidang-bidang pengetahuan di luar musik pula ([3], [4]).

Sangat penting bahwa seorang konselor memahami psikologi musik dengan baik, diperlukan pengetahuan terhadap berbagai proses pendengaran dan proses kerja otak yang menjadi dasar-dasar proses fisiologis terjadinya persepsi musik [17]. Selain itu, dengan memahami psikologi musik, seorang konselor dimungkinkan untuk menjelaskan berbagai pengalaman musikal dan merancang jenis musik yang sesuai bagi konselinya [21]. 


\section{TEKNIK-TEKNIK DALAM MUSIC THERAPY}

Dalam penerapannya, teknik dalam terapi musik itu dibagi menjadi dua, yaitu passive music therapy dan active music therapy [7]. Terapi musik pasif (passive music therapy) adalah pemberian terapi musik yang dilakukan dengan cara mengajak konseli untuk mendengarkan sebuah instrumen tertentu secara seksama. Sedangkan, terapi musik aktif (active music therapy) adalah proses pemberian terapi musik yang dilakukan dengan cara mengajak konseli untuk memainkan sebuah instrumen, bernyanyi, maupun menciptakan lagu [6]. Kedua teknik terapi musik ini dapat dilakukan melalui konseling individual maupun kelompok [17].

Proses pemberian kedua teknik ini dalam praktik konseling, konselor dapat melakukan kegiatan seperti mendengarkan musik kepada konseli, melakukan improvisasi, dan menciptakan lagu. Dengan mengajak konseli untuk mendengarkan musik, dapat membantu konseli mengubah suasana hati mereka menjadi lebih positif, dan mengurangi tingkat kecemasan yang mereka alami. Ketika konselor bekerja dengan konseli dengan menggunakan musik, improvisasi dapat dicapai secara konkret dengan meminta konseli untuk melakukan variasi pada tema musik yang ada (Wigram 2004, dalam [17]). Konselor dapat mengajak konseli untuk memainkan alat musik mereka dan mengubah melodi (yaitu, membuat musik menjadi lebih cepat, lebih lambat, atau divariasikan). Teknik yang terakhir yang dapat digunakan ialah dengan menciptakan lagu. Proses menciptakan dan mengembangkan sebuah lagu, dipandang sebagai terapi yang berasal dari dalam diri konseli itu sendiri (Nordoff \& Robbins, 1977 dalam [17]). Menciptakan lagu adalah tindakan kreatif yang menempatkan konseli berada pada perasaan mereka sendiri. Hal ini dapat digunakan sebagai cara untuk penyembuhan yang melekat dalam tindakan kreatif (Schmidt, 1983 dalam [17]). Dalam praktek yang sebenarnya, konselor dapat meminta atau mendorong konseli untuk menulis atau menciptakan sebuah karya lagu yang mewakili diri mereka sendiri, sehingga pada sesi berikutnya konseli dapat berbicara tentang pengalaman menciptakan sebuah karya lagu tersebut sebagai bentuk katarsis. Selain itu juga, dalam teknik active music therapy, konselor dapat mengajak konseli untuk menciptakan sebuah lirik lagu yang sesuai dengan permasalahan yang mereka alami untuk membantu konseli menyampaikan perasaan sakit yang dialami sehingga membantunya dalam proses recovery [20].

Terapi musik dirancang dengan pengenalan yang mendalam terhadap keadaan dan permasalahan yang tengah dialami oleh konseli, sehingga teknik yang diberikan akan berbeda untuk setiap individu ([18], [19]). Misalnya saja, ada konseli yang lebih sesuai dengan menggunakan teknik terapi musik aktif, tetapi ada juga yang lebih terbantu dengan teknik terapi musik pasif, ataupun sebaliknya [22]. Setiap terapi musik juga akan berbeda maknanya bagi setiap orang. Kesesuaian terapi musik akan sangat ditentukan oleh nilainilai individual, falsafah yang dianut, pendidikan, tatanan klinis, dan latar belakang budaya ([7], [16]). Namun, semua terapi musik memiliki tujuan yang sama, yaitu membantu mengekspresikan perasaan, membantu rehabilitasi fisik, memberi pengaruh positif terhadap kondisi suasana hati dan emosi, meningkatkan memori, serta menyediakan kesempatan yang unik untuk berinteraksi dan membangun kedekatan emosional antara konseli dengan konselor (konseling individual dan kelompok) maupun antara konseli dengan konseli (konseling kelompok) ([6], [9], [10], [11]). Dengan demikian, terapi musik juga diharapkan dapat membantu mengatasi stres, mencegah penyakit dan meringankan rasa sakit yang dialami oleh seorang individu ([6], [16], [17]).

\section{EFEKTIVITAS Music THERAPY UNTUK MEREDUKSI ACADEMIC ANXIETY}

Studi mengenai layanan konvensional yang dilakukan oleh konselor pendidikan terbukti kurang efektif. Penelitian pertama mengenai penggunaan layanan konseling kelompok dengan pendekatan cognitive yang dilakukan terhadap mahasiswa di University of Hormozgan, Iran, terbukti kurang efektif dalam mereduksi academic anxiety mahasiswa terhadap skripsi [23]. Penelitian berikutnya ialah mengenai penggunaan layanan konseling kelompok dengan "systematic motivational counseling" (SMC), terbukti bahwa hasilnya kurang signifikan dalam mereduksi academic anxiety yang dialami oleh mahasiswa [24].

Pada dasarnya seorang individu yang mengalami anxiety disebabkan oleh produksi hormon tiroksin yang tinggi dalam otak manusia. Seseorang yang mengalami proses emosional yang negatif akan merangsang hipotalamus memproduksi hormon tiroksin yang tinggi. Hal tersebut yang menyebabkan individu mudah lelah, mudah cemas, mudah tegang, mudah takut, dan susah tidur, sehingga keadaan individu menjadi kurang optimal (Vianna, Barbosa, Carvalhaes, \& Cunha (2012 dalam [1]). Untuk menanggulangi hal tersebut, seseorang harus dapat menyeimbangkan diri dalam setiap kondisi yang dialami. Otak manusia memiliki empat morfin alami tubuh, yaitu hormon positif yang dapat meredakan penyakit dan membuat hidup menjadi bahagia. Morfin-morfin tersebut ialah hormon endorphin, dopamin, serotonin, dan oksitosin. Fungsi dari morfin-morfin alami ini dapat membuat tubuh menjadi lebih rileks, sehingga dapat mereduksi kecemasan atau stres [5]. Salah satu intervensi untuk meningkatkan produksi hormon endorphin dan serotonin ialah dengan melakukan relaksasi melalui mendengarkan musik [7]. Secara psikologis, musik memiliki hubungan yang positif dalam kehidupan manusia. Musik dapat membuat seseorang menjadi lebih rileks, mengurangi stres, menimbulkan rasa aman dan sejahtera, meningkatkan rasa bahagia, meningkatkan kecerdasan, meningkatkan rasa percaya diri, dan membantu melepaskan rasa sakit [6]. Hal ini diperkuat juga oleh penelitian yang membuktikan bahwa musik dapat meningkatkan produksi hormon endorphin dan serotonin yang mengakibatkan seorang individu dapat merasa lebih bahagia dan mereduksi kecemasan yang dialami ([11], [22]).

Musik sebagai suatu intervensi yang dapat dilakukan dalam membantu seorang individu dalam mereduksi kecemasan telah banyak terbukti. Penelitian yang dilakukan oleh Sharma dan Jagdev [25] menunjukkan bukti bahwa 
dengan penggunaan musik dapat mereduksi stress akademis yang dialami oleh 30 orang remaja. Selanjutnya, penelitian yang dilakukan oleh Lilley, Obercle, dan Thompson [10] juga membuktikan efektivitas musik dapat mereduksi kecemasan sebelum melakukan performance. Penggunaan musik juga dapat diberikan dalam proses konseling. Musik dapat digunakan untuk membantu individu memahami perkembangan emosi dan kognitif mereka. Individu dapat mendengarkan lagu, ataupun memainkan alat musik secara aktif. Melalui musik, konselor dapat membuat proses konseling menjadi lebih menarik dan efektif [18]. Ada beberapa teknik yang dapat membantu konselor dan konseli dalam melakukan reframing ide, memfokuskan perspektif, eksternalisasi emosi, dan memperdalam pemahaman dari sebuah pengalaman atau masalah. Salah satunya ialah melalui musik [19]. Penggunaan musik dalam proses konseling memiliki banyak manfaat yang terapeutik. Musik dapat dijadikan sebagai salah satu strategi konseling berupa teknik relaksasi untuk mengurangi, menurunkan dan mengatasi kecemasan dan ketegangan emosi ([17], [20]). Teknik relaksasi merupakan coping skill yang efektif untuk menurunkan tingkat kecemasan. Musik digunakan sebagai media untuk menenangkan, dan membantu konseli untuk merasa nyaman, sehingga proses konseling menjadi lebih efektif. Penggunaan musik dalam proses konseling dikenal sebagai music therapy. Kajian bahwa music therapy sebagai salah satu bentuk intervensi terapi ekspresif atau seni kreatif dalam pendekatan konseling integratif (integrative approach), yang dapat diterapkan dalam proses konseling juga dijelaskan secara konkret ([3], [4]).

Terapi musik yang dilakukan di College of Notre Dame, Belmont, California menggunakan stimulus suara (bunyi, musik) untuk mengetahui dampak suara terhadap kondisi stres dan rileks yang dialami seseorang, saat ini telah mendunia [6]. Namun penerapan terapi musik ini masih jarang ditemukan, karena masih merupakan hal yang baru, khususnya dalam konseling. Terapi musik dapat berdampak positif untuk mengatasi kecemasan. Terapi musik merupakan teknik yang sangat mudah dilakukan dan terjangkau, namun efeknya cukup besar. Studi metanalisis mengenai musik sebagai media terapi pernah dilakukan di Indonesia [8]. Dari hasil studi metaanalisis tersebut, disarankan bahwa musik dapat digunakan sebagai pendekatan dalam membantu individu yang mengalami hambatan kondisi fisik, perilaku, dan psikologis agar mampu menjadi lebih baik. Penelitian mengenai pengaruh musik sebagai media terapi terhadap kecemasan akademik mahasiswa juga pernah dilakukan [1]. Dari hasil penelitian tersebut, musik dapat digunakan sebagai intervensi untuk menurunkan academic anxiety yang dialami oleh mahasiswa penyusun skripsi. Namun, penelitian ini hanya membuktikan penggunaan musik Mozart sebagai passive music therapy (terapi musik pasif) saja, dan belum mengkaji tentang pemberian musik dalam teknik active music therapy (terapi musik aktif).

\section{KESIMPULAN}

Berdasarkan uraian di atas dapat disimpulkan ialah bahwa pemberian intervensi konseling melalui music therapy lebih efektif dibandingkan dengan layanan konseling konvensional. Jika para konselor atau psikolog pendidikan dapat melakukan layanan konseling dengan music therapy ini, niscaya dapat memberikan pemahaman baru bagi dunia pendidikan di Indonesia bahwa saat ini sudah saatnya beralih ke salah satu pendekatan modern yang jauh lebih efektif. Harapan setelah ini ialah tidak ada lagi berita-berita di media masa mengenai mahasiswa Indonesia yang melakukan perilaku bunuh diri akibat dari kecemasan yang berlebihan terhadap skripsi. Kajian ini dapat menjadi suatu topik yang menarik untuk diteliti di masa depan agar lebih memperkuat thesis statement yang diajukan sebelumnya, bahwasanya harus ada penelitian yang secara konkret membahas tentang efektivitas konseling yang dilakukan oleh seorang konselor atau psikolog pendidikan dengan menggunakan intervensi music therapy dalam membantu para mahasiswa mereduksi kecemasan akademiknya terhadap skripsi. Hal ini dirasa perlu untuk melakukan penelitian lebih lanjut mengenai perbedaan efektivitas pemberian terapi musik dengan teknik passive music therapy dan active music therapy untuk membuktikan teknik yang paling efektif dalam mereduksi academic anxiety mahasiswa terhadap skripsi.

\section{DAFTAR PUSTAKA}

[1] Rosanty, R. (2014). Pengaruh musik mozart dalam mengurangi stres pada mahasiswa yang sedang skripsi. Journal of Educational, Health and Community Psychology, 3(2), 71-78.

[2] Ottens, A.J. (1991). Coping with academic anxiety. New York: The Rosen Publishing Group.

[3] Capuzzi, D., \& Gross, D.R. (2011). Counseling and psychotherapy: Theories and intervention (5th ed.). New Jersey: Merril Prentice Hall.

[4] Sharf, R.S. (2012). Theories of psychotherapy and counseling. Concepts and cases (5th ed.). California: Brooks/Cole.

[5] Mucci, R. dan Mucci, K. (2002). The healing sound of music. Jakarta: PT Gramedia Pustaka Umum

[6] Djohan. (2006). Terapi musik teori dan aplikasi. Yogyakarta: Galangpress.

[7] Wigram, T., Pedersen, I.N., \& Bonde, L.O. (2002). A comprehensive guide to music therapy: Theory, clinical practice, research and training. London: Jessica Kingsley Publisher, Ltd.

[8] Dewi, M.P. (2015). Studi metaanalisis: Musik untuk menurunkan stres. Jurnal Psikologi, 36(2), 106-115.

[9] Ilie, G. (2013). Effects of individual music playing and music listening on acute-stress recovery. Canadian Journal of Music Therapy, 19(1), 23-46.

[10] Lilley, J.L., Oberle, C.D., \& Thompson Jr, J.G. (2014). Effects of music and grade consequences on test anxiety and performance. Psychomusicology: Music, Mind, and Brain, 24(2), 184.

[11] Laura, D., Sylvie, J., \& Aurore, S. (2015). The effects of music therapy on anxiety and depression. Ann Depress Anxiety, 2(4), 1057.

[12] Giovagnoli, A.R., Oliveri, S., Schifano, L., \& Raglio, A. (2014). Active music therapy improves cognition and behaviour in chronic vascular encephalopathy: A case report. Complementary Therapies in Medicine, 22(1), 57-62.

[13] Bibb, J., Castle, D., \& Newton, R. (2015). The role of music therapy in reducing post meal related anxiety for patients with anorexia nervosa. Journal of Eating Disorders, 3(1), 50.

[14] Hatice Çiftçi, R.N., \& Öztunç, G. (2015). The effect of music on comfort, anxiety and pain in the intensive care unit: A case in Turkey. International Journal of Caring Sciences, 8(3), 594. 
[15] Atiwannapat, P., Thaipisuttikul, P., Poopityastaporn, P., \& Katekaew, W. (2016). Active versus receptive group music therapy for major depressive disorder: A pilot study. Complementary Therapies in Medicine, 26, 141-145.

[16] Natalia, D. (2013). Terapi musik bidang keperawatan. Jakarta: Mitra Wacana Media.

[17] Gladding, S.T. (2016). The creative arts in counseling. Alexandria, VA - USA: American Counseling Association.

[18] Skudrzyk, B., Zera, D.A., McMahon, G., Schmidt, R., Boyne, J., \& Spannaus, R.L. (2014). Learning to relate: Interweaving creative approaches in group counseling with adolescents. Journal of Creativity in Mental Health, 4(3), 249-261.

[19] Bradley, L.J., Whiting, P., Hendricks, B., Parr, G., \& Jones Jr, E.G. (2014). The use of expressive techniques in counseling. Journal of Creativity in Mental Health, 3(1), 44-59.

[20] Gladding, S.T., Newsome, D., Binkley, E., \& Henderson, D.A. (2015). The lyrics of hurting and healing: Finding words that are revealing. Journal of Creativity in Mental Health, 3(3), 212-219.

[21] White, S.D., \& Davis, N.L. (2011). Integrating the expressive arts into counseling practice: Theory-based interventions. New York: Springer Publishing Company.
[22] Zarate, R. (2016). Clinical improvisation and its effect on anxiety: A multiple single subject design. The Arts in Psychotherapy, 48,46-53.

[23] Zarei, E., Fini, A.A.S., \& Khajehzadeh Fini, H. (2010). A comparison of effect of group counselling methods, behavioural, cognitive and cognitive-behavioural to reduce students: Test anxiety in the University of Hormozgan. Procedia-Social and Behavioral Sciences, 5, 22562261.

[24] Ghasemzadeh, A. (2011). Effects of group "systematic motivational counseling" (SMC) on university student's academic achievement and test anxiety. Procedia-Social and Behavioral Sciences, 30,2482-2486.

[25] Sharma, M., \& Jagdev, T. (2012). Use of music therapy for enhancing self-esteem among academically stressed adolescents. Pakistan Journal of Psychological Research, 27(1), 53. 